INTERNATIONAL JOURNAL OF
ORGANIZATIONAL LEADERSHIP
ORGANIZATIONAL
LEADERSHIP

\title{
Fourth Industrial Leadership Index (4IRLI) for Manufacturing Companies in Malaysia
}

\author{
Salina Daud ${ }^{1}$, Wan Noordiana Wan Hanafi ${ }^{2 *}$, Jegatheesan Rajadurai ${ }^{3}$, Nurhidayah \\ Mohamed Othman ${ }^{4}$
}

\author{
${ }^{1,3,4}$ College of Business Management \& Accounting, Universiti Tenaga Nasional, Malaysia \\ ${ }^{2}$ Institute of Energy Policy and Research (IEPRe) and College of Business Management and Accounting, \\ Universiti Tenaga Nasional, Malaysia
}

\begin{abstract}
Keywords:

Fourth Industrial Leadership,

Leadership, Industry 4.0,

Manufacturing, Index

\section{Received}

08 November 2021

Received in revised form

02 December 2021

Accepted

07 December 2021

*Correspondence:

diana.hanafi@uniten.edu.my

Industry 4.0 affects all business areas as companies need both virtual and physical structures to enable collaboration between machines, devices, and people, as well as rapid adaptation along the value chain. A strong leader will help the smooth execution of Industry 4.0. This study aims to capture the indicators that will assist in designing the Fourth Industrial Leadership Index (4IRLI) in the manufacturing sector. The data collection for this study includes a focus group discussion, in-depth interview, an expert opinion interview, and a survey. Based on experts' comments and recommendations, the questionnaire was modified to remove vague statements, redundant terms and improve the flow and structure of the questions. The Partial Least Square (PLS) approach is used to analyse the collected data. The Complexity Leadership theory is used as an underlying theory in the study. This study will produce a 4IRLI for manufacturing companies highly involved with the industrial revolution. In doing so, this study will be supporting government initiatives to transform the manufacturing industry into Industry 4.0. This is in line with the United Nations' Sustainable Development Goals, which aim to build resilient infrastructure, promote sustainable industrialisation, foster innovation, and ensure sustainable consumption and production patterns.
\end{abstract}

CCIKD Publishing

The world is now in the fourth stage of the industrial revolution, known as Industry 4.0. Industry 4.0 can be described as an umbrella term, referring to a range of current concepts affecting several industry disciplines (Lasi et al., 2014). Industry 4.0 would bring a digital lifestyle where automation and the Internet of Things (IoT) would be extensively applied in almost all aspects of daily life. The fourth and new digital industrial revolution describes the vision of tomorrow's 
manufacturing: smart factories, machines, raw materials, and products communicate with each other and cooperatively manage production processes (Amberg \& McGaughey, 2017).

The rapid advancement of technology, especially in Industry 4.0, influences every aspect of our lives, including leaderships settings across the world (Schwab \& Davis, 2018). Industry 4.0 takes manufacturing to a new level by integrating cyber and physical systems within or across organisations. It will also use Artificial Intelligence, IoT, Cloud Manufacturing, and Additive Manufacturing technologies, which will enable organisations to be customised and capable of flexible manufacturing of products to meet customer needs (Guzmán et al., 2020). However, Industry 4.0 is not limited to only industrial production. It is manifested in all aspects of society, including technology, production, consumption, and business, and it is influencing every field of human life (Lalanda, Morand, \& Chollet, 2017; Sheng-Feng \& Cheng, 2017; Theorin et al., 2017).

Companies are converting their workplaces into digital workplaces across different sectors and regardless of organisation size. Haddud and McAllen (2018) observed that many jobs now involve extensive use of technology and require the ability to exploit it at a fast pace. Yet, digitalisation is perceived both as a global job destroyer and creator, driving a profound transformation of job requirements. As a result, leaders need to invest in upskilling their talents to support and motivate employees in the face of Industry 4.0. In addition, leaders need to break out of their comfort zones and develop relationships with different people, including physical, biological, political, socioeconomic, functional, and cultural differences (Cote, 2017). According to Sacavém et al. (2019), leadership plays a fundamental role in influencing and moving subordinates to achieve effective and efficient organisational goals.

It has become apparent that organisations are currently looking to embrace Industry 4.0. However, just deploying high technology is insufficient if there is no relevant workforce structure in place. This is because existing traditional leadership capabilities, styles, and mindsets are not enough to tackle the challenges of digital transformation in the volatile, unpredictable, complex, and ambiguous (VUCA) environment. Therefore, organisations have to be equipped to train, reskill and retain digital talents and digital leaders (Sparkus, 2021). In addition, manufacturing companies need new strategic approaches for holistic human resource management to cope with knowledge and competence challenges related to new technologies and processes of Industry 4.0 (Hecklau et al., 2016).

Therefore, the Fourth Industrial Leadership Index (4IRLI) will guide leaders to identify their skills and ability in order to maximise technological advancements. It could also pave the way for effective leaders' development as they can focus on certain acts and activities that can increase productivity and boost organisational performance.

\section{Literature Review}

\section{Complexity Leadership Theory}

Complexity leadership theory posits that the adaptive function is a process whereby creativity and leadership are dynamic and iterative, resulting in bottom-up innovations spreading throughout the organisation (Uhl-Bien \& Marion, 2009). "Complexity leadership theory" investigates the role of leadership in expediting those processes in organisations through which interdependent actions among many individuals combine into a collective venture (Drath et al., 2008). Creativity and leadership research has found that such broad-based adoption of creative 
ideas throughout the organisation is associated with successful new product launches (James, Wooten, \& Dushek, 2011). As such, innovation results from an intricate process of leadership and creativity in managing ideas, opportunities, processes, and tools to offer enhanced products and services (Subramaniam \& Youndt, 2005). Furthermore, leadership behaviours can support creative efforts at a fundamental level by creating conditions conducive to enabling creative outcomes (Shalley \& Gilson, 2004; Tierney \& Farmer, 2004; Zhou \& George, 2003). Complexity leadership theory broadens this perspective to posit leadership not only enables creative outcomes, but also is intertwined with the creative process itself.

Given this intertwined nature of creativity and leadership in producing innovation, and creativity occurring within a collective, leadership is thus a shared, collective process (Day, Gronn, \& Salas, 2004; Ensley, Hmieleski, \& Pearce, 2006). To date, the application of complexity theory to organisational leadership has been criticised as being rich in theory and analogy while being relatively poor in data and results (Avolio, Walumbwa, \& Weber, 2008). However, applying the concepts of complexity theory to the study of leadership has resulted in complexity leadership, which suggests a radically new paradigm for leadership. The core leadership processes posited within this theory are the administrative and adaptive functions (Sweetman, 2010). Overall, in the era of constant business environmental changes, large corporations should increase adaptiveness to prolong the changes for further successful development (Hay, 2017).

\section{Leadership 4.0}

The primary idea of Industry 4.0, according to Oberer and Erkollar (2018), is the integration of machines, processes, and systems by creating intelligent networks along the supply chain and manufacturing process to control each other independently. Since automation and connectivity in a field will move the industrial world and job competition will become linear, Industry 4.0 is a period of technological disruption (Oztemel \& Gursev, 2020). One of Industry 4.0's distinguishing features is the use of artificial intelligence, one example of which is the employment of robots to replace human labour in order to make it cheaper, more effective, and efficient (Kiel et al., 2017).

The leadership skills required for Industry 4.0 are a mix of leadership styles. According to Hensellek (2020), digitalisation is the driving force for the future success of organisations in Industry 4.0. However, classic leadership styles do not sufficiently address the opportunities and challenges arising from digitalisation. This calls for a new approach to leadership, what has been termed "Leadership 4.0." Leadership 4.0 is fast, cross-hierarchical, team-oriented, and with a cooperative approach, with a strong innovation focus (Oberer \& Erkollar, 2018). Furthermore, leadership 4.0 is about leaders creating their digital transformation strategy and ensuring that it is aligned with their organization's business and growth plans.

Again, leaders play a vital role in the fourth industrial revolution in ensuring the effectiveness and success of their organisation. According to Alkahtani (2015), the suitability of leadership styles to be used in an organisation is based on the business sector in which they are operating. Torres and Fyke (2013) also explained that leaders need to investigate the future, anticipate opportunities, and be prepared and ready to act. Leaders also need to break out of their comfort zone and develop relationships with different people, including physical, biological, political, socioeconomic, functional, and cultural differences. Therefore, leadership 
in the fourth industrial revolution era can be regarded as a leadership model that is fast, teamoriented, cross hierarchical, and cooperative, which is called digital leadership; it has a strong focus on innovation (Guzmán et al., 2020).

\section{Indicator of Leadership 4.0}

Every leadership style has different indicators. Several researchers have previously explored this topic and have identified different indicators in measuring leadership in the fourth industrial revolution. For instance, Helena and Ellyn (2019) identified six indicators, (1) responsibility and accountability, (2) systems leadership, (3) technology leadership, (4) entrepreneurial leadership, (5) adaptive leadership, and (6) shaping societies. On the contrary, Wan Noordiana, Salina, and Nur Lyana (2018), in their study on leaders in the fourth industrial leadership, had listed the following indicators: visionary, courage, passion, strategic thinking/ planner, focus, collaborate, innovate, willingness to change and communication. Not surprisingly, the need for a new leadership approach was one of the main topics at World Economic Forum 2021. It was stated that the new model should include team-oriented, cooperative, agile, inspiring, and crosshierarchical digital leaders who also have an ethical responsibility.

Similarly, Bernard (2019) constructed fourteen indicators which included being humbly confident, actively agile, culturally intelligent, visionary, courageous, authentic, able to focus, collaborative, flexible, accountable, tech-savvy, emotional intelligence, and intuitive. Considering the different attributes suggested by different authors, this study will be adapting the following attributes: 1) visionary, 2) courage, 3) idealised influences, 4) inspirational motivation, 5) innovative, 6) passion, 7) strategic thinking, 8) focus, 9) collaborate, 10) willingness to change, 11) communication, 12) accountable, 13) tech-savvy, 14) entrepreneurial, and 15) agile.

Visionary is a suitable indicator for leaders in Fourth Industrial Revolution as visionary leaders have a clear idea of how the future should look. They set out concrete steps to bring the vision to life, and then they lead a team of people in that direction (Prestiadi, Zulkarnain, \& Sumarsono, 2019). Courage, on the other hand, according to Voyer (2011), is an essential ingredient for effective leaders in order to see difficult situations and accept responsibility for the outcomes of decisions and actions. Leaders will work with others in 4IR, but if they do not have the courage to express their ideas and feelings, they will do injustice to themselves and their followers. Leaders with idealised influences attributes can inspire their followers to find new ways to face challenges and solve problems. Idealised influence, therefore, plays a vital role in helping employees reach and exceed performance expectations, assisting them in both personal and organisational changes (Alahmad, 2016).

Next, Rawung, Wuryaningrat, and Elvinita (2015) consider the role of inspirational motivation, noting its role in building trust and satisfaction for the employee. Inspirational motivation refers to the leader's ability to inspire confidence, motivation, and a sense of purpose in his followers. According to these authors, inspirational motivation can serve as the foundation for knowledge sharing, an important component of facilitating the organization's success. Being innovative is also an important indicator of Industry 4.0; innovation is considered a core concept. The dynamic environment factor, due to VUCA, pushes the leader to be more creative and always think innovatively through inbuilt capability or collaboration. 
In particular, it is necessary not only to implement technological systems as technological innovation but, above all, to develop innovative work behaviours (Lukes \& Stephan, 2017).

An equally important indicator is passion. Patel, Thorgren, and Wincent (2015) suggested that a leader's passion may be one factor that could play a key role in pursuing strategic actions. Other than that, leaders need to have strategic thinking. According to Sheppes, Suri, and Gross (2015), strategic thinking solves strategic problems that combine a rational and convergent approach with a creative and divergent thought process. Employing strategic thinking enables one to analyse, explore, understand, and define a complex situation and then develop planning actions to achieve a pre-defined goal's greatest possible positive impact (Kazmi, Naarananoja, \& Wartsila, 2016). Also, similarly, Patel, Thorgren, and Wincent (2015) suggested that a leader needs to have passion, as it may be one factor that could play a fundamental role in pursuing strategic actions and making strategic decisions.

In the same way, besides all of the other variables discussed, leadership also requires focus. The focus indicator concerns the leader's capability to move the organisation from focusing on the current situation to the adoption of the new vision, and it includes the communication of the vision to others, the formulation of a strong guiding coalition, and the focus on new priority areas and niches (Abuzaid, 2016). While the pace of the future workplace will be quick and require flexibility, a future leader will need to maintain focus on the organisation's objectives. Moving toward Industry 4.0 will also require leaders to focus on adopting new technology. Aside from focus, collaboration is also important, where the diversity of future workspaces further amplifies it. With employees coming from different backgrounds and parts of the world, they need strong leaders to appreciate and leverage the differences of every individual to benefit the team and the organisation.

Unquestionably, willingness to change is important for a leader, as positive change is vital because Industry 4.0 requires change. Successful organisations incorporate change within their organisational framework. Any organisation is founded to meet needs. Since human needs are constantly changing or shifting to new needs, organisations are always required to change, especially when working towards Industry 4.0 (Abbasi Asl et al., 2017). Clearly, despite creating readiness, leaders should also encourage employees to commit to change (Santhidran, Chandran, \& Borromeo, 2013). Additionally, communication is at the heart of the interconnectedness of Industry 4.0. By raising speed, efficiency, and smartness of execution, this interconnectedness can be a dramatic force for good. Advanced technologies can have complex societal and ethical implications that require leaders to make difficult decisions about using these tools responsibly. Proactive communication within the organisation will be key to success. Communication, therefore, is one of the key imperatives for the 4th Industrial leadership.

Further, accountability is an important indicator as it can respond to disruptive changes and ensure a human-centred approach to the current challenges (Hughes, 2020). Leaders will need to earn the respect of their team by holding themselves accountable. The workplace of the future will become more transparent and collaborative. In this environment, it is crucial for a leader's actions to align with the company's goals and objectives. Accountability and being tech-savvy are equally important, as in moving towards Industry 4.0, undoubtedly, leaders ideally serve as a link between rapidly evolving technologies, machines, and people. Furthermore, high 
technology is the heart of Industry 4.0. Leaders in Industry 4.0 need to be technology-driven to drive the organization's digital transformation.

The next indicator is entrepreneurial. It refers to identifying marketplace opportunities and discovering the most appropriate ways and time to capitalize on them. For instance, the use of digital technologies combined with modern leadership styles such as entrepreneurial allows lower-level employees to enjoy greater freedom and even a certain degree of self-leadership as long as they contribute to the organisational goals (Innocenzi et al., 2019). The rapid speed of change in the Fourth Industrial Revolution means that leaders need to be agile in embracing change. These indicators are important to cater to the changing demands of employees, working environments, and business tools, which is crucial as strategies that work today may not work in the future. Hence, leaders need to keep up with change and make the best out of it. While much remains unknown about Industry 4.0, at least one thing is for certain are leaders of tomorrow will need unique knowledge and skills to navigate the path to business success. Thus, the attributes discussed above fit Industrial Revolution 4.0 as it is synonymous with creating innovation and new changes.

\section{Research Methodology}

\section{Sample and Sampling Technique}

In this study, a quantitative research method was adopted. The intended respondents in this study are employees from the middle to top level of management in Malaysian manufacturing companies. The list of companies was drawn from the Federation of Malaysian Manufacturers directory, 2020. The unit of analysis of this study is the individuals who are senior executives, managers, and top-level managers. The questionnaires were distributed to the above persons for two main reasons. First, they have the greatest access to essential data related to company activities, and second, they are knowledgeable about the overall activities undertaken by the companies. The sample was obtained randomly to ensure that the selected teams adequately represented the population surveyed.

The sample size for this study was determined using power analysis, a test that seeks to minimize statistical error (a), directly relating sample size and expected effect size. Besides that, research in the social, behavioural, and biomedical sciences have used power analysis to determine the sample size (Faul et al., 2007). Thus, using GPower software, version 3.1, assigning power of $80 \%$, for an expected effect of 0.15 , a $5 \%$ error, and 15 predictors, the minimum sample size of this research is 139 (see Figure 1). However, we set out to collect data slightly larger than the required number. The size of manufacturing companies was measured using the Federation of Malaysia Manufactures (FMM) Directory guideline. 


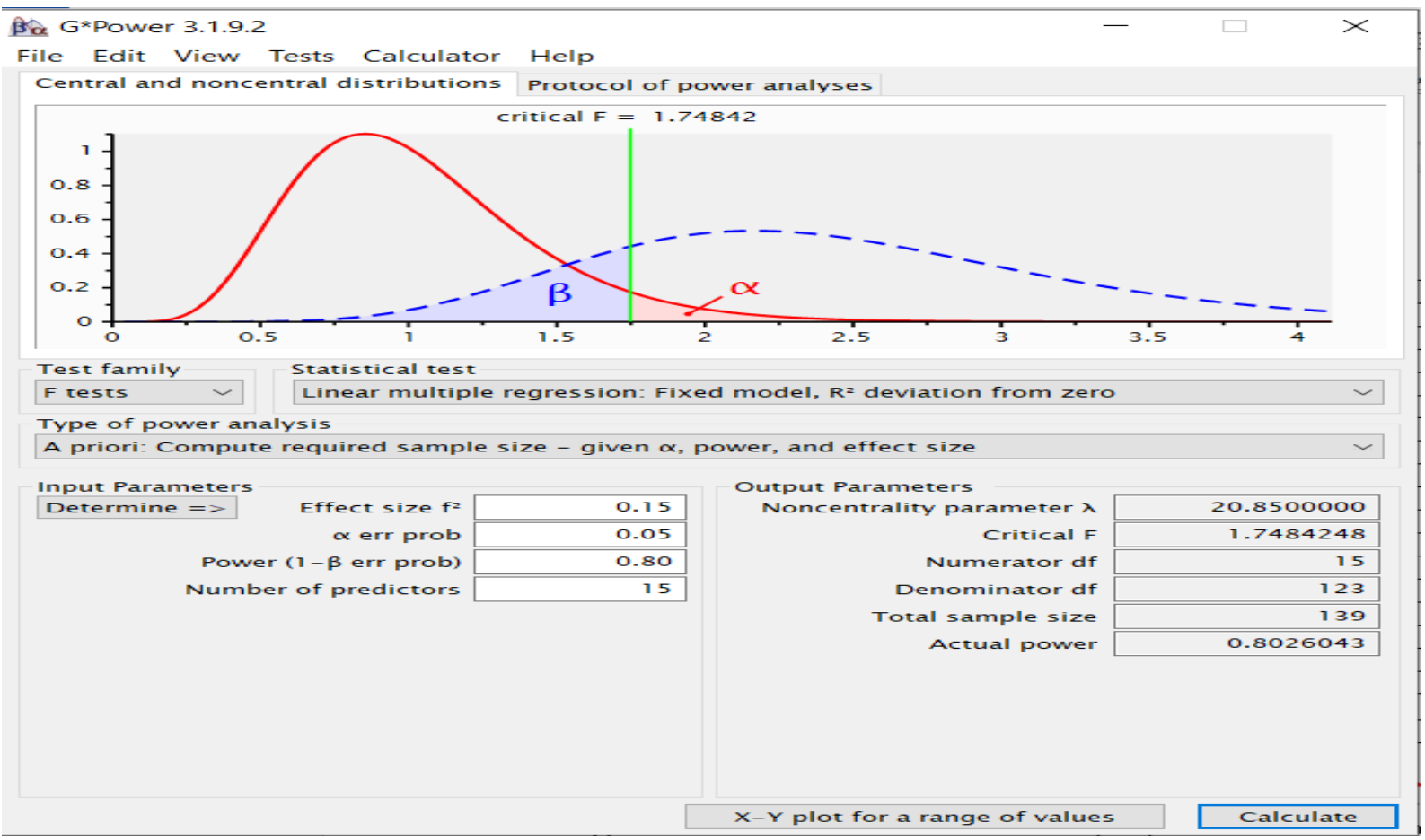

Figure 1. G*Power Analysis

\section{Respondent Profile}

The respondents' profile includes their age, race, the highest level of education, job position, number of years working in the present position, and number of years working in the current industry. The study analysed the data with a total of 315-sample respondents, out of which 115 respondents were aged between 20-30 years old, 114 respondents aged between 31-40 years old, 41-50 years old (47 respondents), and 51-60 years old (9 respondents). Regarding race, 206 respondents were Malay, 55 respondents were Chinese, and 52 respondents were Indian. As for education level, the highest number of respondents are those with bachelor's degrees, with 228 respondents. The next questions were regarding the respondent's job position; from the total of 315 respondents, it can be concluded that the highest number of respondents were from a senior executive, with a total of 205 respondents. For the number of years working in the present position, 157 respondents had less than five years. Lastly, for the number of years working in the current industry, the highest number was for less than five years, with 106 respondents.

\section{Instrument and Instrumentation}

The measurement items were constructed based on previous studies. The purpose of employing an established measurement from previous studies was to link with them and fill the research gap that was identified in the theoretical framework. The quality of the adapted items regarding their reliability and validity has already been examined in prior studies (Bryman et al., 2007). Therefore, it gave the researchers confidence that these items are likely to produce satisfactory reliability and validity and increase the likelihood of expanding the use of the construct to a larger context. The responses for each item were based on a 5-point Likert-type scale ranging from (1) strongly disagree to (5) strongly agree. The instrument used to capture leaders' responses to the Fourth Industrial leadership is as indicated in Table 1. The variables such as visionary, courage, idealised influences, inspirational motivation, innovative, passion, strategic thinking, focus, collaborative, willingness to change and communication were adapted from 
Wan Noordiana, Salina, and Nur Liyana (2016), while accountable, tech savvy, entrepreneurial and agile were adopted from Helena and Ellyn (2019). The variables are adapted because it is suitable as it was done in the Malaysian context; however, the variable by Helena and Ellyn (2019) is adopted because the research is done in Europe, where it needs to be modified according to the Malaysian context.

Table 1

Measurement Item

\begin{tabular}{|c|c|c|c|c|}
\hline Variable & $\begin{array}{l}\text { No. of } \\
\text { items }\end{array}$ & Sample of item use & $\begin{array}{c}\text { Adopted/ } \\
\text { Adapted Item }\end{array}$ & Source \\
\hline Visionary & 8 & $\begin{array}{l}\text { "I have the confidence to aim for things other think are } \\
\text { impossible" }\end{array}$ & Adapted & \multirow[t]{11}{*}{$\begin{array}{l}\text { Wan Noordiana et } \\
\text { al. (2016) }\end{array}$} \\
\hline Courage & 3 & $\begin{array}{l}\text { "I always try to provide structure and organisation to } \\
\text { team." }\end{array}$ & Adapted & \\
\hline Idealised influences & 4 & "I encouraged my subordinate to promote a new idea." & Adapted & \\
\hline $\begin{array}{l}\text { Inspirational } \\
\text { motivation }\end{array}$ & 4 & $\begin{array}{l}\text { "I am often able to help the team to work more } \\
\text { efficiently." }\end{array}$ & Adapted & \\
\hline Innovative & 7 & $\begin{array}{l}\text { "I invest significant time and resources in the } \\
\text { innovativeness strategies." }\end{array}$ & Adapted & \\
\hline Passion & 3 & $\begin{array}{l}\text { "I always encourage others to develop a different } \\
\text { alternative solution to overcome challenges." }\end{array}$ & Adapted & \\
\hline Strategic thinking & 4 & "I initiate action to create possibilities for the future." & Adapted & \\
\hline Focus & 4 & $\begin{array}{l}\text { "I focus on continuous improvement of the organisation } \\
\text { process." }\end{array}$ & Adapted & \\
\hline Collaborative & 5 & $\begin{array}{l}\text { "I identify and encourage opportunities for collaboration } \\
\text { across or within the group." }\end{array}$ & Adapted & \\
\hline $\begin{array}{l}\text { Willingness to } \\
\text { change }\end{array}$ & 3 & $\begin{array}{l}\text { "I encourage my subordinate to adapt by changing } \\
\text { overall strategy, goals, or projects to fit the situation." }\end{array}$ & Adapted & \\
\hline Communication & 3 & $\begin{array}{l}\text { "I create the environment for others where there are no } \\
\text { barriers in communication." }\end{array}$ & Adapted & \\
\hline Accountable & 4 & "I ensure the appropriate used of employee's data" & Adopted & \multirow{4}{*}{$\begin{array}{l}\text { Helena and Ellyn } \\
\text { (2019) }\end{array}$} \\
\hline Tech Savvy & 4 & $\begin{array}{l}\text { "I ensure my subordinates possess the skills to lead in the } \\
\text { digital economy." }\end{array}$ & Adopted & \\
\hline Entrepreneurial & 3 & $\begin{array}{l}\text { "I always create the environment and culture to unlock } \\
\text { the innovation of others in the organisations." }\end{array}$ & Adopted & \\
\hline Agile & 3 & $\begin{array}{l}\text { "I always keep up with the high-velocity change in the } \\
\text { industry." }\end{array}$ & Adopted & \\
\hline
\end{tabular}

In order to fine-tune the survey, the full questionnaire with adapted measurement items was examined and refined in two steps: pre-test and pilot study (Straub, Boudreau, \& Gefen, 2004). For this research, the pre-test was done in two steps. First, several experts in leadership, which included active practitioners and academicians in leadership, who were based in Malaysia, were approached to seek their views. All these experts validated the suitability of the research questionnaire to be used in the Malaysian context. Experts were provided with a printed version of the survey questionnaire. They were asked to provide feedback on the clarity of content, the overall design of the questionnaire, and the sequence of presenting the statements to avoid respondents' bias (Ray \& Tabor, 2003). They commented on wording, the flow of questions, and clarification for having similar questions. Based on experts' comments and recommendations, changes were made to the questionnaire to remedy the vague statements, eliminate unnecessary or redundant terms, and improve the flow and structure of the questions. Second, after modifying the questionnaire based on the experts' comments, a focus group discussion was carried out. A focus group discussion was conducted with nine leaders from different organisations in Malaysia. Potential interview candidates were contacted via email and phone to arrange interview meetings. An open-ended questioning technique was employed, 
where it focused on the fourth industrial leadership attributes. It is a form of group interview that capitalizes on conversations between research practitioners to examine the questionnaire's format, clarity of instructions and statements of items, content representation, ease of understandability, length, and speed of completion (Merriam \& Grenier, 2019). The focus group discussion allowed the opportunity for the leaders to provide essential voices and perspectives about the questionnaire. Discussion during the focus group concentrated on the leadership practices and their opinion on fourth industrial leadership questions. Based on their comments, a minor change to the wording of the instrument was made.

Lastly, a pilot study was conducted before administering the actual survey. The responses from the pilot test were used to improve the clarity of individual questions and format. These adjustments were sought to improve the reliability and validity of the survey instrument, ensuring the question would produce the data necessary to support the research. A comment box was provided for participants to give comments on the questionnaire at the end of the survey. In addition, the reliability of the response data of the pilot study was established using the Composite Reliability evaluation.

\section{Method of Analysis}

The quantitative empirical data collected were then analysed in line with the objectives of the research using the Partial Least Square Equation Model (PLS-SEM). PLS-SEM was used to examine the Confirmatory Factor Analysis (CFA) by using the recommendation value suggested by Hair et al., 2019).

\section{Data Analysis}

An index is a composite measure of variables, indicators, or a way of measuring a construct using more than one indicator. It is an accumulation of scores from a variety of individual indicators that are designed to show changes in a variable or group of related variables with respect to time, geographic location, or other characteristics (Stephanie, 2018). To create an index, one must select possible indicators, examine their empirical relationships, score the index, and validate it. This study had adapted the guidelines suggested by Crossman (2019) to determine the Leadership 4.0 Index, which sought the validation of the indicators of Leadership 4.0 through the face and content validity, uni-dimensionality, and empirical relationships of indicators included in the index. All the examined steps are elaborated in detail below.

\section{Face and Content Validity}

The first step in creating an index is to select the appropriate indicators to be included in the index to measure a variable of interest. For this research, the Leadership 4.0 Index was selected from the indicators pertaining to visionary, courage, idealised influence, inspirational motivation, innovative, passion, strategic thinking, focus, collaborative, willingness to change, communication, accountable, tech savvy, entrepreneurial and agile. Face and content validity are necessary because invalid items may threaten the reliability of findings. Unclear instructions and statements could cause frustration for the respondents, resulting in them dropping the survey without completing the entire questionnaire (Ray \& Bhunia, 2013). The content validity of these indicators was verified further using expert opinions and focus group discussion. Thus, a few experts in leadership, who included active practitioners and academics in the area of leadership, based in Malaysia were approached to seek their views. After modifying the 
questionnaire based on the experts' comments, a focus group discussion was conducted. The focus groups comprised middle to top-level managers in Malaysia's manufacturing sector. Potential candidates were contacted by email and phone to set up the interviews. The Leadership 4.0 indicators were addressed using an open-ended questioning approach. A total of nine managers were selected for this study. The focus group discussion allowed the leaders to provide essential voices and perspectives about the indicators' use and the questionnaire. Discussion during the focus group concentrated on the leadership practices and their opinion on leadership 4.0 indicators that could help enhance leaders in Industry 4.0.

\section{Uni-dimensionality}

Uni-dimensionality of the items plays an important role, explicitly or implicitly, during an initial item construction process. Thus, ensuring that the indicators measure what they are intended to measure is necessary prior to creating an index. One way to verify the unidimensionality is using factor analysis, which groups a certain set of items into factors and determines the loadings of each item on the factors (Hair et al. , 2010).

Item analysis and factor analysis are frequently utilised to analyse the index's association to the different measures it includes. This is addressed using reliability and validity evaluations. There are two traditional approaches to factor analyses as the most widely used technique: (1) Exploratory Factor Analysis (EFA) and (2) Confirmatory Factor Analysis (CFA). However, according to Ziegler and Hagemann (2015), CFA is a step forward in terms of testing for unidimensionality when compared to EFA. Hence, uni-dimensionality is tested using the CFA method using the Partial Least Square Structural Equation Model (PLS-SEM) approach. Some evidence exists that simple SEM models could be meaningfully tested even if the sample size is quite small Hoyle and Kenny (1999), but usually, $\mathrm{N}=100-150$ is considered the minimum sample size for conducting SEM (Anderson \& Gerbing, 1988; Ullman, Tabachnick, \& Fidell, 2001).

Next, before conducting the CFA, since data were collected using a single source, the issue of Common Method Bias was first tested, following the suggestions of Kock and Lynn (2012) and Kock (2015) by testing the full collinearity. In this method, all the variables will be regressed against a common variable, and if the VIF $\leq 3.3$, then there is no bias from the singlesource data. The analysis yielded that the VIF was less than 3.3; thus, single-source bias is not a serious issue with the data (see Table 2).

Table 2

Full Collinearity Testing

\begin{tabular}{|l|l|}
\hline & \\
\hline Visionary & 2.8 \\
\hline Courage & 1.9 \\
\hline Idealized influences & 2.7 \\
\hline Inspirational motivation & 2.6 \\
\hline Innovative & 3.1 \\
\hline Passion & 2.5 \\
\hline Strategic thinking & 2.5 \\
\hline Focus & 2.4 \\
\hline
\end{tabular}

\begin{tabular}{|l|l|}
\hline & \\
\hline Collaborative & 3.0 \\
\hline Willingness to change & 2.6 \\
\hline Communication & 2.3 \\
\hline Accountable & 2.5 \\
\hline Tech Savvy & 2.5 \\
\hline Entrepreneurial & 2.4 \\
\hline Agile & 3.0 \\
\hline & \\
\hline
\end{tabular}

Next, using the two-stage approach suggested by Henseler and Fassott (2010) and Ringle, Sarstedt, and Straub (2012), the second-order reflective Leadership 4.0 was measured using construct scores derived from the first-order constructs (Becker, Klein, \& Wetzels, 2012). For 
the second-order construct, the validity and reliability of the measurement were also assessed. First, the loadings, average variance extracted (AVE), and discriminant validity were assessed for validity. As suggested by Hair et al. (2019), the values of loadings should be $\geq .7$, and the AVE should be $\geq .5$. As shown in Table 3, the loadings and AVEs are higher than the recommended value of .5, as suggested by Hair et al. (2019). Next, discriminant validity was used using the HTMT criterion suggested by Henseler, Ringle, and Sarstedt (2015) and updated by Franke and Sarstedt (2019). The HTMT values should be $\leq .85$, the stricter criterion, and the mode lenient criterion should be $\leq .90$. As shown in Table 4, the values of HTMT are all lower than the stricter criterion of $\leq .85$. We can conclude that the respondents understood that the nine constructs are distinct.

As for reliability, the composite reliability (CR) was assessed. Following the recommended value by Hair et al. (2017), the CR should be $\geq$.7. As for this study, the CR value is all higher than .7 (Table 3). Taken together, both these validity tests have shown that the measurement items are both valid and reliable.

Table 3

CFA Result

\begin{tabular}{llccc}
\hline Second order variable & First order variable & Loading & CR & AVE \\
\hline Leadership 4.0 & Visionary & .70 & .88 & .50 \\
& Courage & .88 & .91 & .78 \\
& Idealized influences & .81 & .89 & .67 \\
& Inspirational motivation & .78 & .90 & .71 \\
& Innovative & .87 & .92 & .61 \\
& Passion & .81 & .85 & .67 \\
Strategic thinking & .79 & .88 & .64 \\
& Focus & .82 & .89 & .68 \\
Collaborative & .81 & .90 & .65 \\
& Willingness to change & .78 & .83 & .62 \\
& Communication & .70 & .75 & .54 \\
& Accountable & .76 & .85 & .59 \\
& Tech Savvy & .74 & .84 & .59 \\
Entrepreneurial & .87 & .91 & .78 \\
\hline
\end{tabular}

Table 4

Discriminant Validity (HTMT)

\begin{tabular}{|c|c|c|c|c|c|c|c|c|c|c|c|c|c|c|c|}
\hline & $\# 1$ & $\# 2$ & $\# 3$ & $\# 4$ & $\# 5$ & $\# 6$ & $\# 7$ & $\# 8$ & $\# 9$ & $\# 10$ & $\# 11$ & $\# 12$ & $\# 13$ & $\# 14$ & $\# 15$ \\
\hline \multicolumn{16}{|l|}{ \#1 Visionary } \\
\hline \#2 Courage & .63 & & & & & & & & & & & & & & \\
\hline \#3 Idealized influence & .79 & .50 & & & & & & & & & & & & & \\
\hline \#4 Inspirational & & & & & & & & & & & & & & & \\
\hline motivation & .75 & .64 & .66 & & & & & & & & & & & & \\
\hline \#5 Innovative & .75 & .62 & .78 & .71 & & & & & & & & & & & \\
\hline \#6 Passion & .70 & .54 & .66 & .84 & .74 & & & & & & & & & & \\
\hline \#7 Strategic thinking & .77 & .52 & .56 & .74 & .65 & .76 & & & & & & & & & \\
\hline \#8 Focus & .68 & .56 & .58 & .65 & .66 & .76 & .77 & & & & & & & & \\
\hline \#9 Collaborate & .63 & .69 & .57 & .80 & .63 & .68 & .75 & .74 & & & & & & & \\
\hline $\begin{array}{l}\text { \#10 Willingness to } \\
\text { change }\end{array}$ & .71 & .51 & .72 & .70 & .75 & .83 & .66 & .58 & .65 & & & & & & \\
\hline \#11 Communication & .73 & .73 & .73 & .76 & .71 & .74 & .72 & .74 & .65 & .81 & & & & & \\
\hline \#12 Accountable & .65 & .43 & .64 & .69 & .60 & .75 & .62 & .65 & .65 & .85 & .79 & & & & \\
\hline \#13 Tech savvy & .63 & .63 & .64 & .74 & .61 & .70 & .66 & .64 & .70 & .74 & .75 & .83 & & & \\
\hline \#14 Entrepreneurial & .58 & .42 & .65 & .64 & .53 & .56 & .58 & .52 & .61 & .82 & .80 & .71 & .72 & & \\
\hline \#15 Agile & .72 & .56 & .60 & .75 & .61 & .68 & .71 & .69 & .72 & .76 & .84 & .80 & .79 & .76 & \\
\hline
\end{tabular}




\section{Evaluation of Significance and Relevance of Indicator Path Coefficient Value}

Next, the empirical relationships among the indicators included in the index were examined. If two indicators are empirically related to each other, then both indicators reflect the same concept and, therefore, can be included in the same index. Thus, following the suggestions of Hair et al. (2019), this study reported the path coefficients, the standard errors, and t-values for the structural model using a 5,000-sample re-sample bootstrapping procedure (Ramayah et al., 2018). For an indicator to be a significant measurement of a variable, the path coefficient of this indicator with the variable it intends to measure should be higher than .1 , and the t-value should be more than 1.645 at $p<.05$ or more than 2.33 at $p<.01$ (Lohmöller, 1989) (see Figure 2). As presented in Table 5, all fifteen indicators were accepted as it has a significant relationship. Thus, no indicators were removed.

Table 5

Bootstrapping Result

\begin{tabular}{|c|c|c|c|c|c|}
\hline & Std $\beta$ & $t$ & $p$ & BCI LL & BCI UL \\
\hline Visionary -> Leadership 4.0 & .13 & 18.35 & .00 & .12 & .14 \\
\hline Courage -> Leadership 4.0 & .07 & 18.22 & .00 & .06 & .07 \\
\hline Idealized Influence -> Leadership 4.0 & .09 & 21.17 & .00 & .08 & .10 \\
\hline Innovative -> Leadership 4.0 & .16 & 23.89 & .00 & .14 & .17 \\
\hline Inspirational Motivation -> Leadership 4.0 & .09 & 18.75 & .00 & .08 & .10 \\
\hline Passion -> Leadership 4.0 & .06 & 16.89 & .00 & .06 & .07 \\
\hline Strategic Thinking -> Leadership 4.0 & .08 & 22.98 & .00 & .08 & .20 \\
\hline Focus -> Leadership 4.0 & .09 & 17.61 & .00 & .07 & .10 \\
\hline Collaborate -> Leadership 4.0 & .11 & 23.79 & .00 & .10 & .12 \\
\hline Willingness to Change -> Leadership 4.0 & .06 & 18.40 & .00 & .05 & .06 \\
\hline Communication -> Leadership 4.0 & .05 & 5.25 & .00 & .04 & .07 \\
\hline Accountable -> Leadership 4.0 & .08 & 18.23 & .00 & .07 & .08 \\
\hline Tech Savvy -> Leadership 4.0 & .08 & 6.57 & .00 & .07 & .10 \\
\hline Entrepreneurial -> Leadership 4.0 & .07 & 19.48 & .00 & .06 & .08 \\
\hline Agile -> Leadership 4.0 & .08 & 22.43 & .00 & .07 & .09 \\
\hline
\end{tabular}

Note. $95 \%$ confidence interval with a bootstrapping of 5,000

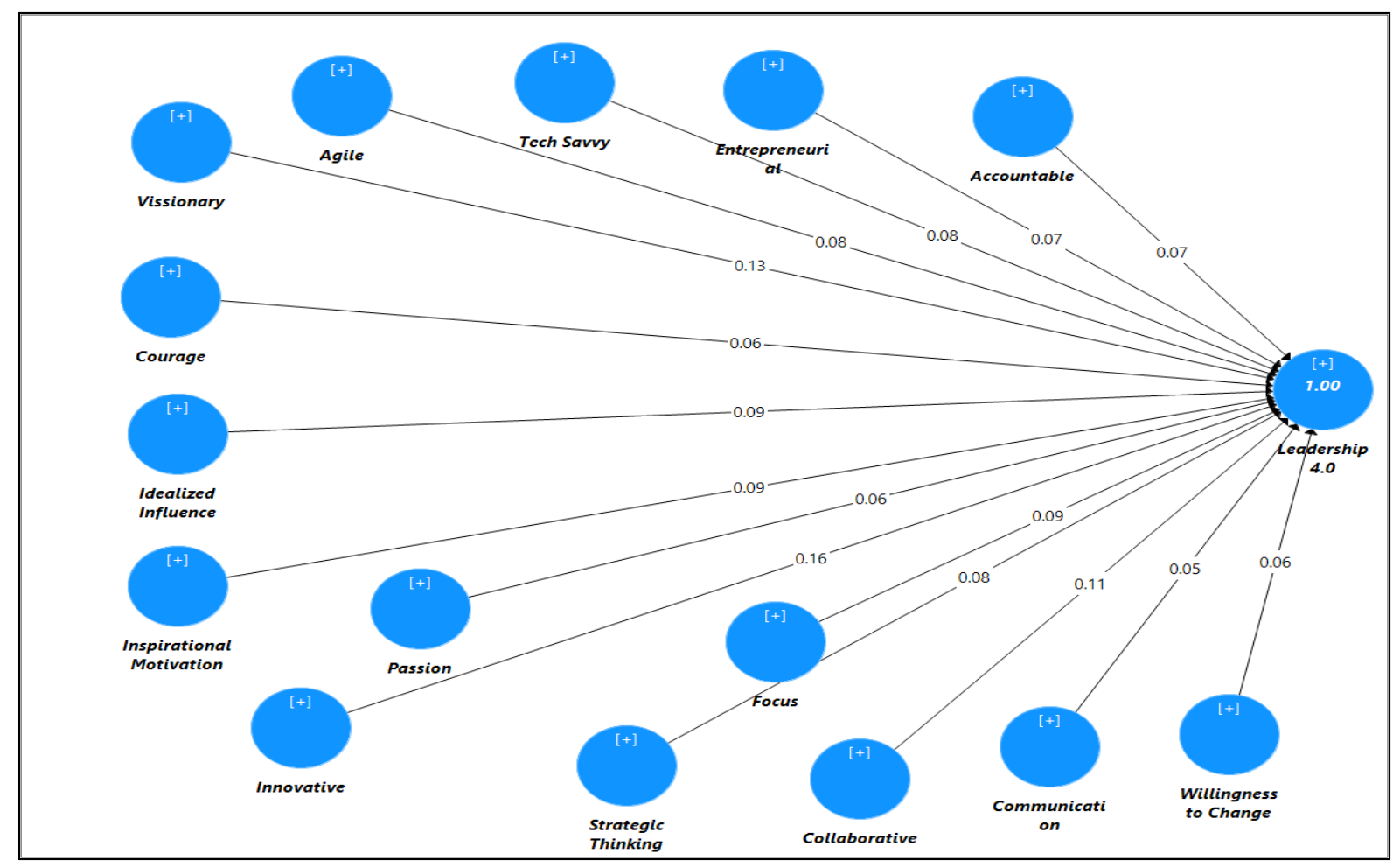

Figure 2. Path Coefficient 


\section{Goodness-of-Fit Index}

Goodness-of-Fit (GOF) is applied as an index for the complete model fit to verify that the model sufficiently explains the empirical data (Tenenhaus et al., 2005). The GOF values lie between 0 and 1 , where values of .10 (small), .25 (medium), and .36 (large) indicate the global validation of the path model. A good model fit shows that a model is parsimonious and plausible (Henseler et al., 2015). The GOF is calculated by using the geometric mean value of the average communality (AVE values) and the average $\mathrm{R}^{2}$ value(s). It was calculated from Table 6 that the GOF index for this study model was measured as 0.52 , which shows that empirical data fits the model satisfactory and has substantial predictive power in comparison with baseline values.

Table 6

Goodness Fit Index Calculation

\begin{tabular}{|c|c|c|}
\hline Construct & AVE & \\
\hline Visionary & .50 & \\
\hline Courage & .78 & \\
\hline Idealized influences & .67 & \\
\hline Inspirational motivation & .71 & \\
\hline Innovative & .61 & \\
\hline Passion & .67 & \\
\hline Strategic thinking & .64 & \\
\hline Focus & .68 & \\
\hline Collaborative & .65 & \\
\hline Willingness to change & .62 & \\
\hline Communication & .54 & \\
\hline Accountable & .59 & \\
\hline Tech Savvy & .59 & \\
\hline Entrepreneurial & .78 & \\
\hline Agile & .78 & \\
\hline Average Values & .65 & \\
\hline AVE X R ${ }^{2}$ & & .27 \\
\hline $\mathrm{GOF}=\sqrt{(}\left(\mathrm{AVE} \times \mathrm{R}^{2}\right)$ & & .52 \\
\hline $\mathrm{R}^{2}$ & & .41 \\
\hline
\end{tabular}

\section{The Standardized Root Mean Square Residual (SRMR)}

The SRMR is the difference between the observed correlation, and the model implied correlation matrix. Thus, it allows assessing the average magnitude of the discrepancies between observed and expected correlations as an absolute measure of (model) fit criterion and can be used to avoid model misspecification. The SRMR is a measure of estimated model fit. When SRMR $=<.08$, then the study model has a good fit (Hair et al., 2019). Table 7 shows that this study model's SRMR was .06, which revealed that this study model had a good fit, whereas the Chi-Square was equal to 2217.08 and NFI equal to .72 .

Table 7

Results Summary for Fourth Industrial Leadership Index Model Fitness

\begin{tabular}{ll}
\hline & Saturated Model \\
\hline SRMR & 0.06 \\
d_ULS & 1.54 \\
d_G & 0.78 \\
Chi-square & 2217.08 \\
NFI & 0.72 \\
\hline
\end{tabular}

\section{Fourth Industrial Leadership Index (4IRLI)}

As the indicators are confirmed and have fulfilled the reliability and validity requirements, the Fourth Industrial Leadership Index (4IRLI) calculation was next. The first step in calculating the index was to find the overall mean for the Fourth Industrial Leadership variable. Each 
indicator used to represent Leadership 4.0 was treated as an independent variable. The way to establish 4IRLI was through multiple regression analysis. In this analysis, the Beta Coefficient Values $(\beta)$ in the multiple regression analysis and the Path Coefficient Values in the Partial Least Square (PLS) analysis were the same (Hair et al., 2017; Hussain et al., 2018). In this study, the researchers used the Path Coefficient Value for each indicator from Figure 1 to calculate the 4IRLI. The Path Coefficient Value for each indicator was totalled to produce the Sum of Path Coefficient Value for the fifteen indicators used. The Path Coefficient Weight for each indicator was then calculated by dividing the respective indicator's Path Coefficient Value by the Sum of Path Coefficient Value. This Path Coefficient Weight was multiplied by the said indicator's mean to establish an indicator's index. The same was done for the other fourteen indicators. The individual index of each indicator was totalled, and this sum provided the final index score for Leadership 4.0 (see Figure 3).

The result is obtained from the total 4IRLI presented in Table 8, which shows an index score of 4.43. The rating scales of Excellent $=5.0$, Good $=4.0$, Average $=3.0$, Poor $=2.0$ and Very Poor $=1.0$ (Ha-Vikström \& Takala, 2018; McLeod, 2019) are used. Ideally, if the leaders display a perfect leadership style, their response category for each indicator would be 'Strongly Agree', equating to a Scale of 5 on the Likert Scale. This result conveys a clear message to help organisations better understand their current leadership effectiveness.

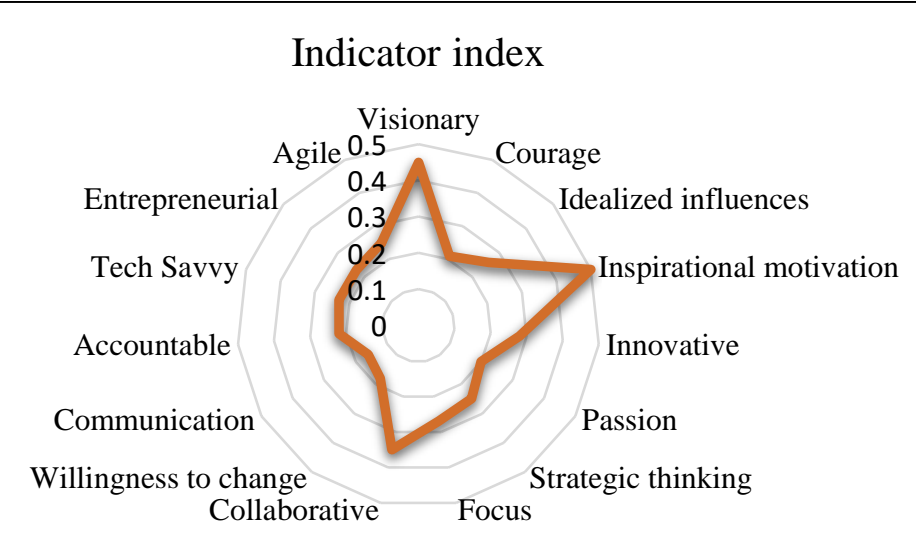

Figure 3. Total indicator index

Table 8

Fourth Industrial Leadership Index (4IRLI)

\begin{tabular}{|c|c|c|c|c|}
\hline Items & Path Coefficient Value & Path Coefficient Weight & Mean & Indicator index \\
\hline Visionary & .13 & .10 & 4.35 & .45 \\
\hline Courage & .07 & .05 & 4.20 & .21 \\
\hline Idealized influences & .09 & .07 & 3.92 & .26 \\
\hline Inspirational motivation & .16 & .12 & 4.08 & .50 \\
\hline Innovative & .09 & .07 & 3.88 & .28 \\
\hline Passion & .06 & .05 & 4.07 & .20 \\
\hline Strategic thinking & .08 & .06 & 3.93 & .25 \\
\hline Focus & .09 & .07 & 4.09 & .27 \\
\hline Collaborative & .11 & .09 & 4.03 & .35 \\
\hline Willingness to change & .06 & .05 & 3.91 & .18 \\
\hline Communication & .05 & .04 & 4.09 & .16 \\
\hline Accountable & .07 & .06 & 3.80 & .22 \\
\hline Tech Savvy & .07 & .06 & 3.93 & .23 \\
\hline Entrepreneurial & .08 & .05 & 4.17 & .23 \\
\hline \multirow[t]{2}{*}{ Agile } & .08 & .06 & 3.91 & .25 \\
\hline & $\begin{array}{c}\text { Sum of Path Coefficient } \\
\text { Value }=1.29\end{array}$ & & & Final index score $=4.04$ \\
\hline
\end{tabular}




\section{Discussion}

The advantage of comparing the index readings of a variable over time is that it enables decision-making in different situations (Charles \& Donaldson, 1984). As the results revealed, the 4IRLI enables leaders to determine their leadership style, strengths, and weaknesses and which indicators need further improvement. Based on the indicator index, the highest number of scores are for inspiration motivation (0.50), visionary (0.45), and collaborative (0.35). It also underlies other vital indicators such as focus, innovative, strategic thinking, agile, entrepreneurial, and tech-savvy. In contrast, other indicators with low scores, as indicated in Table 8, include willingness to change, communication, and courage.

Each indicator is defined with an optimal value (see Table 8). The better the leaders score in each indicator, the higher the index. The indicator result will reflect the leadership profile. In other words, if the answers are far away from the optimal values, the index will be low. Furthermore, the reliability and validity are also reliable, as both values exceed the threshold value. This gives a strong indication of a trustworthy model.

The transition to Industry 4.0 is an evolutionary process in which technologies must be adapted to new manufacturing and innovation management requirements. The management requirements that must be developed include new business models for new markets, new locations, new products and services, and new forms of cooperation and collaboration. In all circumstances, there is no one best leadership style.

The application of leadership attributes may be beneficial in gaining a competitive advantage in the manufacturing industry. Policymakers could use the findings to assess the suitability of training programmes for leaders in the fourth industrial revolution, emphasizing the characteristics of leadership listed above. Implementing the findings of this study into the professional practise of leadership skills could also improve the effectiveness of leadership in the manufacturing sector, which would have a positive impact on productivity over the long term.

In theory, the complexity leadership theory supports the role of leadership in expediting those organization processes among many individuals combined into a collective venture. The core leadership processes posited within this theory are the administrative and adaptive functions (Sweetman, 2010). Thus, in moving towards the Fourth Industrial Revolution context, organization leaders should increase adaptiveness to prolong the changes for further successful development.

In addition, Industry 4.0 also brings significant challenges to organisations; they need to adjust their ways of working regarding technology, overall structure, and strategies. But on the other hand, it can lead to new opportunities, new processes, and high performance. Thus, this 4IRLI is crucial as the next generation of leaders needs to develop the relevant knowledge and skills to help them evolve into digitally transformed leaders.

\section{Conclusion}

Industry 4.0 is often spoken in digital technology rather than focusing on the employees. The tech of Industry 4.0 that many employees fear will replace their jobs. And that is where 4IRLI can play a significant and fundamental role. Leaders who think differently by applying the 4IRLI to their managerial leadership challenges are one step closer to creating an innovative, organisational response to changes resulting from Industry 4.0. To sum up, this study attempts 
to improve understanding of the human contribution to variability in the manufacturing sector. Manufacturing leaders in the industry can use this study's outcome to better understand the importance of leadership and the benefits they bring towards business performance in the company. In conclusion, leaders can use this index to strengthen their leadership skills. This index can be used as an indicator to sustain their strong attributes and improve their poor attributes. The index can be a signal to further improve leaders' capability skills in leading the organisation.

\section{References}

Abbasi Asl, J., Nikzad, H., Taherian, A., Atlasi, M. A., Naderian, H., Mousavi, G., . . . Omidi, A. (2017). Cultural acceptability and personal willingness of Iranian students toward cadaveric donation. Anatomical Sciences Education, $10(2), 120-126$.

Abuzaid, A. N. (2016). Testing the impact of strategic leadership on organizational ambidexterity: A field study on the Jordanian chemical manufacturing companies. International Journal of Business and Management, 11(5), 328-339.

Alahmad, Y. Y. (2016). Understanding the relationship between transformational leadership styles: idealized influence, intellectual stimulation, inspirational motivation, individualized consideration and product innovation among manufacturing and services firms, the role of open system (Doctoral dissertation). University of Toledo. Retrieved from http://rave.ohiolink.edu/etdc/view?acc_num=toledo1460983654

Alkahtani, A. H. (2015). The influence of leadership styles on organizational commitment: The moderating effect of emotional intelligence. Business and Management Studies, 2(1), 23-34.

Amberg, J. J., \& McGaughey, S. L. (2017). Fostering local entrepreneurship in a multinational enterprise: Taylor \& Francis.

Anderson, J. C., \& Gerbing, D. W. (1988). Structural equation modeling in practice: A review and recommended two-step approach. Psychological Bulletin, 103(3), 411.

Avolio, B., Walumbwa, F., \& Weber, T. (2008). Integration of leadership theory, research and practice: What's next. Annual Review of Psychology, 60, 421-449.

Becker, J.-M., Klein, K., \& Wetzels, M. (2012). Hierarchical latent variable models in PLS-SEM: guidelines for using reflective-formative type models. Long Range Planning, 45(5-6), 359-394.

Bernard. (2019). 14 essential leadership skills for the 4th industrial revolution. Retrieved from https://www.forbes.com/sites/bernardmarr/2019/05/13/15-essential-leadership-skills-during-the-4thindustrialrevolution/?sh $=7 \mathrm{a} 913 \mathrm{c} 59 \mathrm{a} 3 \mathrm{a} 0$

Bryman, A., Bell, E., Mills, A. J., \& Yue, A. R. (2007). Business research strategies. Business Research Methods, $226-238$.

Charles, B., \& Donaldson, D. (1984). Social criteria for evaluating population change. Journal of Public Economics, 25(12), 13-33.

Cote, R. (2017). Vision of effective leadership. International Journal of Business Administration, 8(6), 1-10.

Crossman. (2019). How to Construct an Index for Research. Retrieved from https://www.thoughtco.com/index-for-research3026543

Day, D. V., Gronn, P., \& Salas, E. (2004). Leadership capacity in teams. The Leadership Quarterly, 15(6), 857-880.

Drath, W. H., McCauley, C. D., Palus, C. J., Van Velsor, E., O'Connor, P. M., \& McGuire, J. B. (2008). Direction, alignment, commitment: Toward a more integrative ontology of leadership. The Leadership Quarterly, 19(6), 635-653.

Ensley, M. D., Hmieleski, K. M., \& Pearce, C. L. (2006). The importance of vertical and shared leadership within new venture top management teams: Implications for the performance of startups. The Leadership Quarterly, 17(3), $217-231$.

Faul, F., Erdfelder, E., Lang, A.-G., \& Buchner, A. (2007). G* Power 3: A flexible statistical power analysis program for the social, behavioral, and biomedical sciences. Behavior Research Methods, 39(2), 175-191.

Franke, G., \& Sarstedt, M. (2019). Heuristics versus statistics in discriminant validity testing: a comparison of four procedures. Internet Research, 29(3), 430-447. https://doi.org/10.1108/IntR-12-2017-0515

Guzmán, V. E., Muschard, B., Gerolamo, M., Kohl, H., \& Rozenfeld, H. (2020). Characteristics and skills of leadership in the context of Industry 4.0. Procedia Manufacturing, 43, 543-550. 
Ha-Vikström, T., \& Takala, J. (2018). Measuring transformational leadership profiles-an empirical study across 21 nations in a multinational company. Theoretical Issues in Ergonomics Science, 19(1), 1-20.

Haddud, A., \& McAllen, D. (2018). Digital workplace management: exploring aspects related to culture, innovation, and leadership. Paper presented at the 2018 Portland International Conference on Management of Engineering and Technology (PICMET).

Hair, Anderson, R., Babin, B., \& Black, W. (2010). Multivariate data analysis: A global perspective (Vol. 7). Upper Saddle River, NJ: Pearson.

Hair, Risher, Sarstedt, \& Ringle. (2019). When to use and how to report the results of PLS-SEM. European Business Review, 31(1), 2-24. https://doi.org/10.1108/EBR-11-2018-0203

Hair, Sarstedt, M., Ringle, C. M., \& Gudergan, S. P. (2017). Advanced issues in partial least squares structural equation modeling: Sage publications.

Hay, R. A. (2017). Leading with limited knowledge: An application of the theory of complex responsive processes of relating to leadership practice. University of the West of England,

Hecklau, F., Galeitzke, M., Flachs, S., \& Kohl, H. (2016). Holistic approach for human resource management in Industry 4.0. Procedia Cirp, 54, 1-6.

Helena, L., \& Ellyn, S. (2019). Leading through the fourth industrial revolution putting people at the centre. World Economic Forum. Retrieved from https://www.weforum.org/whitepapers/leading-through-the-fourth-industrial-revolution-puttingpeople-at-the-centre

Henseler, J., \& Fassott, G. (2010). Testing moderating effects in PLS path models: An illustration of available procedures. In Handbook of partial least squares (pp. 713-735). Springer.

Henseler, J., Ringle, C. M., \& Sarstedt, M. (2015). A new criterion for assessing discriminant validity in variance-based structural equation modeling. Journal of the Academy of Marketing Science, 43(1), 115-135.

Hensellek, S. (2020). Digital leadership: A framework for successful leadership in the digital age. Journal of Media Management and Entrepreneurship (JMME), 2(1), 55-69.

Hoyle, R. H., \& Kenny, D. A. (1999). Sample size, reliability, and tests of statistical mediation. Statistical Strategies for Small Sample Research, 1, 195-222.

Hughes, H. (2020). Coronavirus: Why employers should be tackling presenteeism [Press release]

Hussain, S., Fangwei, Z., Siddiqi, A. F., Ali, Z., \& Shabbir, M. S. (2018). Structural equation model for evaluating factors affecting quality of social infrastructure projects. Sustainability, 10(5), 1415.

Innocenzi, V., Zueva, S., Prisciandaro, M., De Michelis, I., Di Renzo, A., di Celso, G. M., \& Vegliò, F. (2019). Treatment of TMAH solutions from the microelectronics industry: A combined process scheme. Journal of Water Process Engineering, 31,100780 .

James, E. H., Wooten, L. P., \& Dushek, K. (2011). Crisis management: Informing a new leadership research agenda. Academy of Management Annals, 5(1), 455-493.

Kazmi, S. A. Z., Naarananoja, M., \& Wartsila, J. K. (2016). Integrating strategic thinking and transformational leadership for NPD idea support process. Procedia-Social and Behavioral Sciences, 229, 387-397.

Kiel, D., Müller, J., Arnold, C., \& Voigt, K. (2017). Sustainable industrial value creation: Benefits and challenges of Industry 4.0.[rewarded with ISPIM Best Student Paper Award]. Paper presented at the Conference: International Society for Professional Innovation Management (ISPIM).

Kock, N. (2015). Common method bias in PLS-SEM: A full collinearity assessment approach. International Journal of eCollaboration (IJEC), 11(4), 1-10.

Kock, N., \& Lynn, G. (2012). Lateral collinearity and misleading results in variance-based SEM: An illustration and recommendations. Journal of the Association for Information Systems, 13(7).

Lalanda, P., Morand, D., \& Chollet, S. (2017). Autonomic mediation middleware for smart manufacturing. IEEE Internet Computing, 21(1), 32-39.

Lasi, H., Fettke, P., Kemper, H.-G., Feld, T., \& Hoffmann, M. (2014). Industrie 4.0. Wirtschaftsinformatik, 56(4), $261-264$.

Lohmöller, J. B. (1989). Predictive vs. structural modeling: Pls vs. ml. In Latent variable path modeling with partial least squares (pp. 199-226): Springer.

Lukes, M., \& Stephan, U. (2017). Measuring employee innovation. International Journal of Entrepreneurial Behavior \& Research, 23(1), 136-158. https://doi.org/10.1108/IJEBR-11-2015-0262

McLeod, S. A. (2019). Likert scale. Retrieved from https://www.simplypsychology.org/likert-scale.html

Merriam, S. B., \& Grenier, R. S. (2019). Qualitative research in practice: Examples for discussion and analysis: John Wiley $\&$ Sons. 
Oberer, B., \& Erkollar, A. (2018). Leadership 4.0: Digital leaders in the age of industry 4.0. International Journal of Organizational Leadership, 7(4), 404-412.

Oztemel, E., \& Gursev, S. (2020). Literature review of Industry 4.0 and related technologies. Journal of Intelligent Manufacturing, 31(1), 127-182.

Patel, P. C., Thorgren, S., \& Wincent, J. (2015). Leadership, passion and performance: a study of job creation projects during the recession. British Journal of Management, 26(2), 211-224.

Prestiadi, D., Zulkarnain, W., \& Sumarsono, R. B. (2019). Visionary leadership in total quality management: efforts to improve the quality of education in the industrial revolution 4.0. Paper presented at the 4th International Conference on Education and Management (COEMA 2019).

Ramayah, T., Cheah, J., Chuah, F., Ting, H., \& Memon, M. (2018). Partial least squares structural equation modeling (PLSSEM) using SmartPLS 3.0. In An Updated Guide and Practical Guide to Statistical Analysis: Pearson.

Rawung, F. H., Wuryaningrat, N. F., \& Elvinita, L. E. (2015). The influence of transformational and transactional leadership on knowledge sharing: An empirical study on small and medium businesses in Indonesia. Asian Academy of Management Journal, 20(1).

Ray, B., \& Bhunia, A. (2013). Fundamental food microbiology: CRC press.

Ray, N. M., \& Tabor, S. W. (2003). Several issues affect e-research validity. Marketing News, 37(19), 50-53.

Ringle, C. M., Sarstedt, M., \& Straub, D. W. (2012). Editor's comments: a critical look at the use of PLS-SEM in" MIS Quarterly". MIS quarterly, iii-xiv.

Sacavém, A., Cruz, R. V., Sousa, M., Rosário, A., \& Gomes, J. S. (2019). An integrative literature review on leadership models for innovative organizations. An Integrative Literature Review on Leadership Models for Innovative Organizations, 1741-1751.

Santhidran, S., Chandran, V., \& Borromeo, J. (2013). Enabling organizational change-leadership, commitment to change and the mediating role of change readiness. Journal of Business Economics and Management, 14(2), 348-363.

Schwab, K., \& Davis, N. (2018). Shaping the future of the fourth industrial revolution. Currency.

Shalley, C. E., \& Gilson, L. L. (2004). What leaders need to know: A review of social and contextual factors that can foster or hinder creativity. The Leadership Quarterly, 15(1), 33-53.

Sheng-Feng, Q., \& Cheng, K. (2017). Special Issue on Future Digital Design and Manufacturing: Embracing Industry 4.0 and Beyond-Part II. Chinese Journal of Mechanical Engineering = Ji xie gong cheng xue bao, 30(5), 1045-1046.

Sheppes, G., Suri, G., \& Gross, J. J. (2015). Emotion regulation and psychopathology. Annual Review of Clinical Psychology, $11,379-405$.

Sparkus. (2021). Leadership 4.0: A Call for Leaders to Stay Relevant in the Near Future. Retrieved from https://sparkus.com/leadership-4-0-a-call-for-leaders-to-stay-relevant-in-the-near-future/

Stephanie. (2018). Index Number: Simple Definition. Retrieved from https://www.statisticshowto.com/index-number/

Straub, D., Boudreau, M. C., \& Gefen, D. (2004). Validation guidelines for IS positivist research. Communications of the Association for Information Systems, 13(1), 24.

Subramaniam, M., \& Youndt, M. A. (2005). The influence of intellectual capital on the types of innovative capabilities. Academy of Management Journal, 48(3), 450-463.

Sweetman, D. (2010). Exploring the adaptive function in complexity leadership theory: An examination of shared leadership and collective creativity in innovation networks: The University of Nebraska-Lincoln.

Tenenhaus, M., Vinzi, V. E., Chatelin, Y.-M., \& Lauro, C. (2005). PLS path modeling. Computational Statistics \& Data Analysis, 48(1), 159-205.

Theorin, A., Bengtsson, K., Provost, J., Lieder, M., Johnsson, C., Lundholm, T., \& Lennartson, B. (2017). An event-driven manufacturing information system architecture for Industry 4.0. International Journal of Production Research, 55(5), $1297-1311$.

Tierney, P., \& Farmer, S. M. (2004). The Pygmalion process and employee creativity. Journal of Management, 30(3), 413432.

Torres, D. H., \& Fyke, J. P. (2013). Communicating resilience: A discursive leadership perspective. M/C Journal, 16(5).

Uhl-Bien, M., \& Marion, R. (2009). Complexity leadership in bureaucratic forms of organizing: A Meso model. The Leadership Quarterly, 20(4), 631-650.

Ullman, J. B., Tabachnick, B. G., \& Fidell, L. S. (2001). Using multivariate statistics. Structural Equation Modeling, 653771.

Voyer, P. A. (2011). Courage in leadership: From the battlefield to the boardroom. Ivey Business Journal. 
Wan Noordiana, W. H., Salina, D., \& Nur Liyana, B. (2016). Blue ocean leadership determinants. International Journal of Management and Applied Science, 2(1), 72-75.

Wan Noordiana, W. H., Salina, D., \& Nur Lyana, B. (2018). Blue Ocean Leadership and Emotional Intelligence in Government Link Companies (GLCs): Preparing for Industry 4.0. Paper presented at the SHS Web of Conferences.

Zhou, J., \& George, J. M. (2003). Awakening employee creativity: The role of leader emotional intelligence. The Leadership Quarterly, 14(4-5), 545-568.

Ziegler, M., \& Hagemann, D. (2015). Testing the unidimensionality of items. Hogrefe Publishing.

\section{Acknowledgements}

Special thanks to the Ministry of Higher Education (MOHE), Malaysia, for funding this research through the Fundamental Research Grant Scheme (FRGS).

\section{Disclosure Statement}

No potential conflict of interest was reported by the authors.

\section{Funding Acknowledgements}

Not applicable.

\section{Open Access}

The International Journal of Organizational Leadership publishes open access articles under the terms of the Creative Commons Attribution (CC BY) License, which permits use, distribution, and reproduction in any medium, provided the original work is properly cited. 